REVISTA DE LA UNIVERSIDAD DEL AZUAY

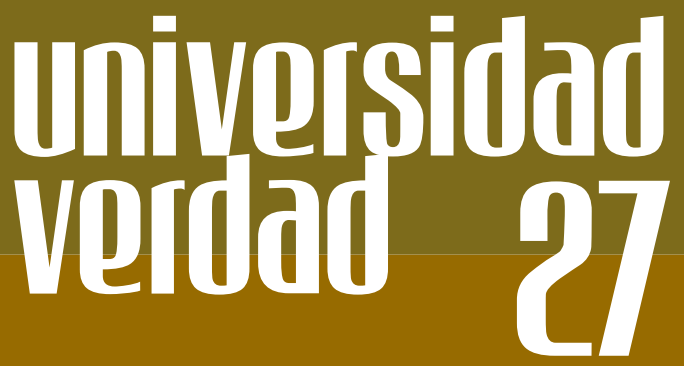

UNIVERSIDAD

DEL AZUAY

\title{
IDENTIDAD Y CONFLICTOS CULTURALES
}

\author{
Juan Cueva Jaramillo
}

Ex Embajador del Ecuador en Francia 
“... tiraron las imágenes al suelo y las cubrieron de tierra y después orinaron encima, diciendo: Ahora serán buenos y grandes tus frutos... lo cual, sabido de ellos, dejaron lo que hacían y corrieron gritando a darle conocimiento a don Bartolomé Colón, que tenía aquel gobierno por el Almirante su hermano, que se había ido a Castilla. Este, como lugarteniente del Virrey y Gobernador de las islas, formó proceso contra los malhechores $y$, sabida la verdad, los hizo quemar públicamente". ${ }^{1}$

El episodio relatado por Fray Ramón Pané en 1498 es aleccionador. Seis indígenas que habían sido convertidos al cristianismo, tomaron unas imágenes religiosas que había dejado el mencionado fraile y las enterraron, como solían hacer con sus propios ídolos, en una ofrenda para que la tierra fecunde. Es decir honraron a las imágenes en gesto de sincretismo religioso y por este acto de fe fueron castigados con la pena suprema, quemados. Es una clara muestra de la concepción etnocéntrica con la cual el europeo juzga a América.

El concepto de etnocentrismo, generado en las ciencias antropológicas, es la actitud de un grupo humano que se coloca como centro alrededor del cual gira el mundo. Dicho grupo posvaloriza positivamente sus realizaciones y particularismos, cree en su superioridad y menosprecia o niega los valores de las culturas diferentes a la suya.

El etnocentrismo se explicita en los conceptos teóricos que manejamos, así como en nuestro lenguaje cotidiano. Cuando hablamos en América Latina del "Cercano Oriente", no pensamos que tal región geográfica es cercana y está al Este para Europa, pero para Latinoamérica es el lejano occidente. Cuando estudiamos el 
bachillerato nos enseñaron la "Historia Universal", que de universal no tiene nada, pues en realidad es la historia de la cuenca del Mediterráneo, es decir de lo que se acostumbra llamar actualmente la Civilización Occidental. Recuerdo por ejemplo que en "Historia Universal" jamás nos enseñaron lo que ocurría durante el siglo XI en la región en que hoy es Bolivia, o qué pasaba en el siglo XIII en el centro de Africa.

Los manuales de historia que se utilizan en nuestras escuelas, colegios y universidades, están plagados de un fuerte contenido etnocéntrico.

Algunos hechos son presentados con gran frecuencia y con lujo de detalles, por ejemplo, el fausto de las Cortes reales o la heroicidad de determinados personajes, o la grandeza de las conquistas militares, sin embargo, en dichos manuales, es difícil encontrar descripciones sobre la miseria, el hambre, la esclavitud, el genocidio, hechos que normalmente deberían inquietar la conciencia de los autores de tales manuales de enseñanza.

Veamos algunos ejemplos, tomados de manuales de Historia actualmente en uso.

Refiriéndose a la acción de los portugueses y españoles en América podemos leer lo siguiente en un texto editado en Suiza:

"...debieron someter a numerosas pobladas aún primitivas. Dos imperios que habían llegado a un nivel de civilización bastante elevado, desaparecen, a la llegada de los españoles: "El Imperio Azteca en México y el Incario en el Perú". ${ }^{2}$

Da la impresión el citado manual de historia de que los europeos al llegar a América debieron someter, por una especie de fatalidad histórica. Si se tratara de la conquista de un pueblo europeo, se diría que hordas invadieron y masacraron, pero como se trata de europeos conquistando América, se dice tan solo que "debieron someter". Los europeos "se instalan", los "pueblos primitivos" agreden. Luego se les 
niega el calificativo de pueblos y se habla de pobladas, a las que se les califica de aún primitivas, dando a entender que hay un determinismo histórico que conduce inevitablemente del "primitivismo" a la "civilización". Finaliza diciendo que los imperios "desaparecen a la llegada" de los españoles, como si dichos pueblos se habrían eclipsado por su propia voluntad, cuando bien sabemos que fueron invadidos, colonizados y pauperizados por un mercantilismo europeo, del que España fue tan solo un eslabón.

Veamos ahora un ejemplo tomado de un manual de historia publicado en la que fue Unión Soviética y que es también fuertemente etnocentrista.

“La anexión del Asia Central a Rusia contribuyó a un rápido desarrollo de la cultura de los pueblos Auzbek, Tarjik y Turkmeno. El estancamiento en que se encontraban tales culturas desde hace siglos, fue reemplazado por una intensa actividad, gracias al acceso de esos pueblos a la cultura rusa y a la cultura europea". 3

Nótese como, según este texto el progreso cultural se logra gracias al aporte de Rusia y Europa. Los pueblos del Asia Central estaban estancados hasta que llegó la anexión salvadora.

Nuestro lenguaje está cargado de tanto etnocentrismo que hablamos corrientemente del "problema negro" en los Estados Unidos, como si la presencia de hombres de origen africano en América no fuera el resultado del comercio de esclavos practicado por los europeos "blancos". En este sentido quizá sería más correcto hablar de un "problema blanco" en los Estados Unidos.

Un procedimiento etnocéntrico generalizado consiste en definir a otra cultura por la ausencia de un fenómeno específico de la cultura del observador. Así por ejemplo se designa con relativa frecuencia a los pueblos asiáticos, africanos y americanos con la expresión "pueblos no-blancos", lo cual no enriquece de ninguna manera nuestro conocimiento sobre dichos pueblos. Es como si para referirnos 
a los claveles y a los nardos, les llamaríamos "no-crisantemos".

Una manual de historia, editado en Portugal, nos trae el siguiente texto:

"...Rosseau sostuvo la doctrina del buen salvaje, actitud romántica desmentida por los antropófagos, los cazadores de cabezas y los traidores que lanzan flechas envenenadas oponiéndose a la colonización blanca". ${ }^{4}$

Se llega aquí al climax del etnocentrismo, al acusar al aborigen de traidor, por no dejarse colonizar, por tratar de mantener su identidad cultural. Si un europeo así procediera, en lugar de traidor, se le calificaría de patriota de la resistencia.

Los ejemplos propuestos nos prueban hasta qué punto el etnocentrismo desfigura la historia, amoldándola a la escala de valores del historiador. Más grave aún es el hecho de que dicha historia tiene pretensiones de verdad absoluta y de universalidad. Es verdad que todos los pueblos, micro-etnias y macro-etnias, están sujetas a una cierta forma de etnocentrismo al relatar sus hazañas y al valorizar sus leyendas, sin embargo en tales casos se trata de su propia historia y no de la Historia, pretendidamente universal.

El etnocentrismo, por otra parte, es un fenómeno muy sutil, generalmente inconsciente y que levanta una barrera que nos impide comprender la diversidad cultural, base indispensable para la construcción de un nuevo orden internacional.

\section{CONFLICTOS CULTURALES}

La indudable situación de pauperismo e injusticia social en que están inmersos los grupos aborígenes de América Latina, debe ser comprendida dentro de una compleja trama de relaciones que vincula a estos grupos de población con la sociedad nacional y con la estructura productiva internacional. Se impone una visión diacrónica 
que nos permita comprender correctamente las relaciones entre etnias y sociedades nacionales en el subcontinente. De otra manera, correríamos el riesgo de caer en la concepción "indigenista", o sea, observar los problemas sin la conexión suficiente con el universo nacional e internacional.

Las relaciones desiguales entre grupos de cultura heterogénea, conllevan relaciones sociales de explotación, que emanan de una estructura socio-económica determinada desde la época colonial. En efecto la colonización europea formó parte de un proceso de expansión política y económica post feudal.

Entendemos por estructura un conjunto de relaciones básicas con un mínimo de estabilidad que caracteriza a todo proceso histórico.

Llamamos sistema a un conjunto de relaciones -consumo, acumulación, distribución, intercambio, etc., que se dan entre los elementos que están macro-integrados.

Cuando hablamos de Colonialismo nos referimos a un sistema socio-económico coherente, que se basa en una relación estructural de dependencia.

En la lógica del sistema, las desigualdades culturales permiten que unos subsistemas asuman el papel de polos hegemónicos o dominantes, y otros el de periferias dependientes.

Debemos evitar caer en el error, tan común para la Antropología tradicional, de considerar el caso indígena como un problema meramente cultural, evitando cuidadosamente tomarlo como un problema político. Aquella hipótesis que nos habla de aislamiento de los indios que formarían otra sociedad, desconectada de la sociedad nacional, es falsa. La visión dualista está cargada de un contenido ideológico indudable, ya sea a nivel consciente o inconsciente.

El mal llamado "problema indígena" se origina en la estructura económica del sistema de producción impuesto en América por 
Europa. El relativo aislamiento cultural y las desigualdades objetivas no son sino parte del síndrome: Consecuencia y no causa. El engranaje del proceso histórico genera una lógica interna en que el problema de las etnias diferenciadas es sólo parte del proceso mayor de relaciones sociales de clase. Así es como se forma una interdependencia económica entre la ciudad-mercado y el hinterland indígena. La población aborigen fue obligada por la Europa postfeudal a aceptar leyes y usos que beneficiaban a los colonizadores, se modificó el régimen de tierras, la tecnología, el gobierno, las relaciones económicas y los patrones culturales.

Darcy Ribeiro ${ }^{5}$ considera que las poblaciones aborígenes pueden encontrarse actualmente en cuatro situaciones: 1. aisladas; 2 . en contacto intermitente; 3 . en permanente contacto; y 4. integradas.

La mayor parte de los grupos aborígenes de América Latina se hallan en el tercer caso, es decir en contacto permanente con la sociedad nacional. La prueba de que es así está dada por el hecho de que las variaciones que se producen en el precio internacional de algunas materias primas, como el caucho y la tagua, pueden dinamizar relativamente o deprimir aún más a diversas poblaciones aborígenes que viven de la recolección de tales materias primas en el medio selvático. Como vemos el caminar de la historia y las marcas del colonialismo han hecho que los aborígenes pasen de la autarquía a la dependencia. Además de aculturación se trata de un problema de colonialismo y neo-colonialismo.

Los contactos que hemos mantenido históricamente con las poblaciones indígenas, no ayudan a tranquilizar nuestra conciencia. La salud, el progreso, el confort, que nuestra sociedad pretende haber aportado al indígena, no le han llegado realmente, sobre todo si pensamos en términos de generalidad. El administrador colonial, el funcionario, el hacendado y hasta el misionero, han contribuido a que el aborigen pierda paulatinamente su propia escala de valores, que no ha sido reemplazada por los valores de nuestra civilización. Hemos intentado privar al indígena de su identidad cultural, de su dignidad humana, lo hemos degradado hasta ubicarle en la más baja 
escala de la sociedad latinoamericana actual. El indio -primer americano cronológicamente- ocupa hoy el último lugar en aspectos educacionales, sanitarios o de ocupación. El indígena está excluido actualmente del nivel de toma de decisiones en América Latina.

El término "primitivo" con el que le designamos con frecuencia es profundamente etnocéntrico, se basa en el solo criterio del bajo nivel tecnológico en relación a nuestra sociedad que posee una tecnología relativamente sofisticada. Nuestra cultura niega los valores del otro, menosprecia lo que le es diferente.

La sociedad nacional dominante transfigura y adecua a sus propios intereses a los aborígenes mediante lo que en Antropología se denominan compulsiones. Ellas son principalmente de cuatro tipos:

A) Compulsiones ecológicas (reducción de habitat; cambios sensibles en el entorno geográfico).

B) Compulsiones bióticas (transmisión, generalmente involuntaria, de enfermedades para las cuales el indígena no ha desarrollado resistencias orgánicas).

C) Compulsiones tecnológico-culturales (cambios en la vivienda; herramientas modernizadas que desplazan a las tradicionales, creando dependencia frente al productor de bienes industriales).

D) Compulsiones ideológicas (frustraciones psicológicas y complejos de inferioridad resultantes del menosprecio de valores aborígenes).

a) Ejemplifiquemos las compulsiones ecológicas con un caso de actualidad que ocurre en el Ecuador.

En la región de selva húmeda con clima tropical amazónico, que los ecuatorianos denominamos Oriente, se han conservado grupos humanos con identidad cultural bien diferenciada. 
Son en general etnias que practican un nomadismo limitado y se nutren básicamente de la recolección de frutos silvestres, de la cacería y de la pesca; practican generalmente un tipo de agricultura incipiente y mantienen contactos intermitentes con la sociedad nacional.

Entre las etnias que viven en el Oriente ecuatoriano podemos citar a los cofanes, los sionas, los secoyas, los shuar y los achuar, los záparos, los canelos, los yumbos, los huaoranis, sin que esta enumeración pretenda ser exhaustiva.

La mayoría de estos grupos humanos enfrenta actualmente el peligro, real e inminente, de su extinción cultural y aun biológica producida por factores exógenos que son, por una parte, el proceso de colonización de tierras por inmigrantes blanco-mestizos que se establecen en regiones que pertenecen a tales etnias $y$, por otra parte, la presencia de compañías nacionales y foráneas dedicadas a exploración y extracción de petróleo y otras materias primas.

Los aborígenes selváticos, al alejarse para evitar el contacto con estos extraños, reducen considerablemente su habitat. Las proteínas y las calorías, que antes podían obtener suficientemente de la recolección, caza y pesca, disminuyen correlativamente con la reducción del entorno ecológico. La desnutrición comienza a manifestarse, pues el sistema de subsistencia practicado tradicionalmente, se vuelve disfuncional. La vida de predación en seminomadismo, exige un ámbito geográfico muy extenso.

Las compañías exploradoras y las autoridades de gobierno a veces ignoran lo que está ocurriendo. Cuando los antropólogos hacemos conocer el problema, frecuentemente se imponen a la supervivencia de grupos minoritarios de la selva. Es inquietante y lamentable saber que estos hechos están ocurriendo ahora, en plena segunda mitad del siglo $X X$. Con las consiguientes variaciones el mismo problema se 
presenta en Guatemala, México, Brasil, Colombia, Perú, Venezuela, para no citar sino a aquellos países en que el problema reviste caracteres de gravedad. Por demás está decir que frecuentemente las empresas exploradoras y extractoras de materias primas, no pertenecen a tales países, sino a otros altamente industrializados.

b) En cuanto a compulsiones bióticas, digamos tan sólo que la población aborigen de México en el año 1520 oscilaba alrededor de los veinte y cinco millones de habitantes, según lo afirma la escuela de Berkeley. ${ }^{6}$ La misma población era de apenas algo más de un millón en los albores del siglo XVII. La curva demográfica posterior es ascendente.

Uno de los factores que contribuyó a tan fuerte despoblamiento, fue el de las enfermedades traídas desde Europa, tales como la tifoidea, la gripe, el sarampión, la coquelucha, etc. que hasta entonces eran desconocidas en América y para las cuales, por lo tanto, los aborígenes no habían desarrollado ningún mecanismo de defensa biológica. Las resistencias orgánicas eran inexistentes y tales enfermedades diezmaron la población. Debemos decir que el contagio y la transmisión de tales enfermedades ocurrió de una manera totalmente involuntaria y, en la mayor parte de los casos, sin que se dé cuenta siquiera el europeo.

Este problema, que hemos usado como ejemplo de compulsión biótica, sigue diezmando las poblaciones aborígenes, sobre todo entre los grupos selváticos que están relativamente aislados de las sociedades nacionales.

c) En lo que respecta a las comunidades tecnológico-culturales, analicemos una de ellas, el caso de la vivienda rural. Es frecuente que grupos silvícolas ocupen tradicionalmente casas comunales, que son un lógico producto del concepto de colectividad, de ayuda recíproca en las faenas cotidianas, de cohesión del grupo social. Ocurre que a veces los agentes 
de desarrollo imbuyen u obligan a los indígenas a abandonar las dichas casas comunales para que pasen a vivir en casas dedicadas a una sola familia, que forman aldeas o pequeños poblados. Tenemos entonces un doble cambio: de las casas comunales desperdigadas a lo largo de los ríos tropicales, pasan a casas unifamiliares ubicadas en aldeas, o sea concentradas. Dicho cambio abrupto rompe el equilibrio social, empobrece cultural y económicamente a la población aborigen, facilitando, por otro lado, las tareas de dominación al concentrar a la población en aldeas.

Otro caso digno de análisis es el de la vivienda en la región interandina. Se trata en este caso de un tipo de vivienda que es producto de un proceso milenario de adaptación al clima de los páramos de la cordillera andina.

El campesino indígena una de la sabiduría popular al seleccionar los materiales para construir su vivienda. Dichos materiales son los más idóneos para enfrentar al viento, al frío, a la llovizna sempiterna de los interandes americanos.

Robustas y anchas paredes de tierra, ya sea de adobe o de "tapial" con puertas muy estrechas y ventanas mínimas, cuando existe alguna; techos de paja recogida en el páramo; hogar central para cocer alimentos y calentarse al mismo tiempo; conejillos de indias (cuyes) que sirven de alimento en los días de fiesta, viven dentro de la casa, contribuyendo al mismo tiempo, con su calor animal, a la calefacción de la vivienda. A veces el techo de paja se prolonga en las paredes, en otras ocasiones en lugar de tierra, se usan maderos y paja en abundancia, en fin, las variaciones regionales son múltiples, caracterizadas todas por una proporción humana siempre presente. Una gran riqueza de elementos arquitectónicos, adaptados a la naturaleza, caracteriza a la vivienda indígena de los Andes.

Nuestra sociedad, en lugar de estudiar esa extraordinaria 
fuente de sabiduría popular, desprecia tales elementos arquitectónicos y los reemplaza con una tecnología ajena a nuestro medio. Las escuelas de Arquitectura de los países andinos (creo que sin excepción) no consideran como materiales de construcción al adobe ni a la paja.

Existen muchos casos de fracaso en la modernización de las viviendas por no haberse consultado a la población interesada y por haber impuesto arbitrariamente soluciones paternalistas sin tomar en cuenta a los factores antropológicos. ${ }^{7}$

Claro está que no se trata de mantener formas arcaicas de construcción con criterio de anticuario romántico, sino de estudiar la vivienda aborigen y, en un proceso de intercambio en pie de igualdad con el indígena, enriquecer mutuamente la arquitectura andina.

d) Un caso de compulsión ideológica típica es la actitud generalizada de los llamados agentes de desarrollo, como el profesor, el asistente social, el cauchero, el misionero, el colono, el hacendado, el tendero, el ingeniero agrónomo, el guardia forestal, el trabajador de empresa petrolera, etc., que menosprecian todo el quehacer indígena, afirmando que su casa no sirve, que su comida es mala, que sus artefactos no valen, que sus ideas son falsas. A fuerza de escuchar repetidamente estas afirmaciones etnocéntricas, el indígena pierde confianza en su propia cultura, termina por renegar de sus valores y de su tradición milenaria. Llega a avergonzarse el indígena de su gente y de sí mismo. Comienza entonces otra vida, una vida de imitación en la que asume otras ideas, otro vestido, otras creencias, es decir pasa paulatinamente a la "civilización" en la que va a ser, salvo excepciones, un hombre de segunda clase.

Entonces vendrá la actitud paternalista. Se dirá, refiriéndose a los indios "los pobrecitos". O, vendrá tal vez la actitud racista, en cuyo contexto la palabra indio se usa como injuria, 
como un grosero insulto. Cuando alguien procede mal en el Ecuador, solemos decir "tenía que ser indio", o "ya se le salió el indio". Esta actitud racista tiende a desaparecer conforme avanza la educación.

\section{¿QUIÉN ES Y QUIÉN NO ES INDIO?}

En las páginas anteriores hemos hablado de los indios, de los aborígenes, de los indígenas... ¿quiénes son? ¿cómo podemos definirlos? ¿en base a qué criterios?

El criterio más común para definir al indio es, puede suponerse, el criterio racial. Ahora bien, conforme avanzan los conocimientos en el campo de la Antropología Física, el concepto de "raza" pierde correlativamente el valor científico. Tanto es así que hoy en día, ningún científico que se precie de tal, maneja el concepto de raza. Además dicha palabra se ha llenado de un cúmulo tal de prejuicios, que su solo uso se vuelve indeseable.

En términos de Arqueología, podemos afirmar que la población americana procede principalmente de cazadores nómadas venidos de Asia a través del estrecho de Behring en olas migratorias sucesivas, en una época anterior a hace cuarenta milenios. Desde luego debemos aceptar otras migraciones posteriores de variado origen.

En un comienzo estos cazadores nómadas asiáticos, podían ser identificados fácilmente por sus características somáticas como son la forma de los ojos, la coloración cobrizo-clara de la piel, la llamada mancha "mongólica" en la región lumbar y ciertas constantes hematológicas como son el factor Diego y la predominación del gruupo sanguíneo $O$.

Claro está que la homogeneidad "racial" de los amerindios no ha pasado de su etapa de hipótesis de trabajo.

A partir del "descubrimiento de América" se produce un mestizaje 
biológico generalizado pues los conquistadores europeos llegaron sin mujer, lo que da como resultado una mezcla genética que produce cambios pertinentes en el aspecto físico.

Los cuatro siglos y medio de mestizaje, nos impiden usar al factor genético como criterio de identificación delindio. El comercio esclavista que llevó africanos a América, hace aún más complejo el intento de utilizar el factor "raza" en el caso que nos ocupa.

Las sociedades nacionales surgidas en América Latina del proceso independentista, dan prioridad al factor clase social; así es como el papel que desempeña cada individuo en las tareas productivas, le ubica en un determinado estrato de una clase social dada.

Un indígena boliviano, o peruano, o mexicano que se viste a la europea, habla español, maneja valores culturales occidentales, posee bienes y tiene a su servicio indios, ya no es considerado como un indio. El criterio social de indígenas es más bien el de aquel individuo que está de hecho llamado a desempeñar las funciones consideradas como menos prestigiosas y que son las peor remuneradas dentro de la sociedad. Subyace también la idea de ruralidad.

No olvidemos que la sociedad colonial presenta dos grupos asimétricamente opuestos: los conquistadores, que detentan el dominio sobre las fuerzas productivas; y los indios, que son el grupo subyugado. Tales grupos no pueden existir aislados en la sociedad colonial, pues, a la par que opuestos, son complementarios. Solamente si hay dominado, alguien puede desempeñar el papel de dominador. ${ }^{8}$

El criterio cultural para tratar de ubicar al indio se basa en su pertenencia, o por lo menos al carácter de heredero, de una cultura que se desenvolvió en el continente americano durante miles de años antes de la llegada de los conquistadores europeos. Sin embargo, desde que América es sometida al proceso colonial, se da una tan acentuada aculturación que hoy es muy difícil identificar y distinguir 
los rasgos culturales provenientes de uno u otro continente. Siguiendo a Aguirre Beltrán ${ }^{9}$ podríamos definir la aculturación como "el proceso de cambio que emerge del contacto de grupos que participan de culturas distintas. Se caracteriza por el desarrollo continuado de un conflicto de fuerzas, entre formas de vida de sentido opuesto, que tienden a su total identificación y se manifiesta, objetivamente en su existencia a niveles variados de contradaicción".

Habría que añadir solamente que en el proceso de aculturación, hay siempre una cultura que impone y otra que es dominada, pues, de otra manera, utilizaríamos más bien la expresión mestizaje cultural.

La cultura de Europa post-feudal que llega a América no tiene la menor intención de mezclarse, de yuxtaponerse, sino de incorporaren-su-seno a los "otros". Juan Ginés de Sepúlveda, al polemizar con Fray Bartolomé de las Casas, dirá que los evangelizadores están dispuestos a asimilar "a esos entes u homúnculos", es decir que la idea de los europeos fue asimilar a los americanos, una vez que éstos hayan renunciado a su identidad cultural.

Este intento de usar rasgos culturales para identificar a los indios, aunque teóricamente es satisfactorio, en la práctica ofrece dificultades múltiples. Las fronteras que separan las dos culturas son muy difíciles de precisar. Con frecuencia se cae en el error de considerar a todo rasgo arcaico como perteneciente a la cultura indígena.

Definir a los indios por la lengua que hablan, es el criterio que más se ha utilizado, sobre todo en los censos, por su facilidad de identificación. Antropológicamente la lengua es un rasgo cultural pertinente. Sin embargo, el bilingüismo tiende a generalizarse y el uso del Español como primera lengua se impone en las nuevas generaciones indias, pues es tomado como un evidente signo de ascenso en el status social.

Por otra parte existen grupos de indios que no hablan sino el Español y han perdido toda memoria de la lengua aborigen americana 
que poseyeron antes de la llegada de los europeos. Este monolingüismo español no parece ser criterio suficiente para negar la calidad de indios a tales grupos humanos.

Como vemos el problema de saber quién es indio y quién no lo es, es mucho más complejo de lo que aparece a primera vista, pues se trata de un concepto etnocultural con un fuerte componente social.

A pesar de todos estos problemas teóricos, en los hechos, las convenciones sociales nos permiten distinguir a los indios de los demás integrantes de la comunidad nacional.

Existen casos de individuos de indudable extracción indígena que ocupan situaciones destacadas en la vida nacional, lo cual parecería probar que lo "racial" no es una barrera. Si analizamos el caso seriamente, encontraremos que cuando un indígena ha ascendido en la escala social hasta lograr un puesto de prestigio, lo ha hecho renunciando a su propia identidad cultural indígena, renunciando su lengua, a sus valores, a su vestido, a sus costumbres y acogiendo dócilmente las reglas de juego de la sociedad dominante. Dicho de otra manera: se asciende dejando-de-ser-indio, renegando de su grupo. Podemos afirmar pues que el ascenso social para los indígenas en América Latina actual es factible a nivel individual, pero no a nivel de grupo.

Los conceptos indio, mestizo, blanco, además de su contenido etnocultural, guardan una estrecha relación con la estructura del poder, y de ahí sus connotaciones políticas.

Incluso si partimos de una hipótesis falsa-base económica igualla-ventaja para el blanco frente al indio en la carrera ascendente dentro del status social, es indiscutible.

La educación es para el indio una suerte de aprendizaje de su dependencia, porque sólo es tomado como objeto de la enseñanza y no como sujeto activo de ella. Las destrezas y los conocimientos aprendidos en la escuela guardan poca o ninguna relación con la vida 
real y cotidiana.

El acceso a la escuela es muy difícil para un campesino-indígena en América Latina. No porque "el indio sea reacio a enviar a sus hijos a la escuela" -como se afirma a veces con ligereza- sino porque cada familia, para lograr completar su presupuesto de supervivencia, necesita del trabajo de todos sus miembros, incluidos los hijos en edad escolar. Enviar a un hijo a la escuela representa para el campesino indígena perder una mano de obra vital, poniendo en peligro la existencia misma del núcleo familiar.

Así es como la escolarización está estructuralmente vinculada a los ingresos económicos y a la posibilidad de nutrirse de cada familia india. No basta construir escuelas, contratar profesores y educar gratuitamente. Es indispensable aumentar el presupuesto familiar de la población campesino-indígena para hacer, de esa manera, factible la educación.

Los antropólogos no podemos contentarnos únicamente con el análisis y la descripción de estos problemas lacerantes. Nuestra tarea es también, y fundamentalmente, el encuentro de caminos idóneos de solución. No debemos aparecer como unos cientistas sociales románticos que soñamos con mantener intocados a grupos humanos en vitrina. Siendo realistas, debemos reconocer y aceptar que el proceso de aculturación es irreversible, pero tenemos la obligación moral y académica de contribuir para que tal proceso sea menos traumatizante para los indios, menos destructor de su identidad cultural. Nosotros, como hombres pertenecientes a la cultura dominante, estamos obligados a llenarnos de una cierta dosis de humildad y rescatar, respetándolos, los valores culturales ajenos.

La Antropología debe contribuir a diseñar una política cultural correcta en América Latina, que sepa tener en cuenta las múltiples diversidades etnoculturales existentes. Hasta hoy sólo ha existido en forma implícita una política cultural condicionada por las estructuras sociales dominantes. Es necesario reorientar y explicitar dichas políticas de acuerdo a las nuevas realidades de este mundo en 
proceso de cambio y en búsqueda de un nuevo orden internacional, más justo y menos segregacionista. ${ }^{10}$

En la elaboración de esa nueva política cultural, la participación directa en la toma de decisiones de los grupos indígeno-campesinos y las etnias silvícolas, es el camino más idóneo para enderezar siglos de dominación, de colonialismo y de actitudes paternalistas.

\section{NOTAS}

1. Fray Ramón Pané. Relación acerca de las antigüedades de los indios. Capítulo XXVI, pp. 53 y 54. Ed. Siglo XXI. Segunda edición. México 1977.

2. Histoire Général du XIV au XVIII siécle. E. Giddey. Lausanne. Payot 1968. Citado por R. Preiswerk y D. Perrot. Ethnocentrisme et Histoire. Ed. Anthropos. Paris 1975. pp. 120.

3. J. A. Fedossov. Historia de la URSS. Prosvetchenie. Moscú 1971.

4. Historia Geral da Civilizaçao. Adriano Vazco Rodriguez. Porto Editora. Porto 1968-1969. Citado por R. Preiswerk y D. Perrot. Ethnocentrisme et Histoire. Ed. Anthropos. Paris 1975. pp. 249.

5. Darcy nRibeiro. Fronteras Indígenas de la Civilización. Ed. Siglo XXI. México 1971.

6. Cfr. L'Indigénisme mexicain. Henry Favre. Problemas d'Amerique Latine. La documentation Française. № XLII. Paris 1976.

7. Cfr. Nutrición y Desarrollo en los Andes Ecuatorianos. IMSE. Obra de equipo. Ed. Artes Gráficas. Quito 1975. El autor analiza en esta obra el fracaso de las viviendas de San Agustín del Callo en el Ecuador.

8. Segundo Moreno. Sublevaciones Indígenas en la Audiencia de Quito. Estudios Americanistas de Bonn. Bas 5. Bonn 1975. pp. 382.

9. Gonzalo Aguirre Beltrán. El proceso de aculturación y el cambio sociocultural en México. Instituto de Ciencias Sociales. México 1970, pp. 36.

10. Cfr. Darío Moreira. La Política Cultural en Ecuador. UNESCO. París 1977. 


\section{BIBLIOGRAFÍA}

AGUIRRE BELTRÁN, Gonzalo. El proceso de aculturación y el cambio socio-cultural en México. Ins. de Ciencias Sociales. México 1970.

BURGOS, Hugo. Relaciones Interétnicas en Riobamba. México 1970.

FAVRE, Henry. L'Indigénisme Mexicain. Problémes d'Amérique Latine. La documentation Française № XLII. París 1976.

GONZALES CASANOVA, Pablo. Sociología de la Explotación. México 1973.

JAULIN, Robert. Le livre blanc de l'ethnocide en Amérique. Ed. Fayard. París 1972.

JIJÓN Y CAAMAÑO, Jacinto. Antropología prehispánica del Ecuador. Ed. Prensa Católica. Quito 1972.

MOREIRA, Darío. La Política Cultural en Ecuador. UNESCO. París 1977.

MORENO YÁNEZ, Segundo. Sublevaciones indígenas en la Audiencia de Quito. BAS. 5. Estudios Americanistas de Bonn. Ed. Herausgeber. Udo Oberem. Bonn 1976.

PANE, Fray Ramón. Relaciones acerca de las antigüedades de los indios. Ed. Siglo XXI. México 1977.

PREISWERK, Roy et PERROT, Dominique. Ethnocentrisme et Histoire. Ed. Anthropos. París 1975.

RIBEIRO, Darcy. Fronteras Indígenas de la civilización. Ed. Siglo XXI. México 1971,

STAVENHAGEN, Rodolfo. Las clases sociales en las sociedades agrarias. Mèxico 1975.

VARIOS. Nutrición y desarrollo en los Andes Ecuatorianos. Ed. Artes Gráficas. Quito 1975. 